\title{
日 本農村医学会雑誌
}

第 20 巻昭和 46 年 9 月 第 3 号

\section{一へき地農山村における出稼ぎ労働者の健康とその社会的背景}

第 1 報 出稼ぎ労働者の健康破壊について

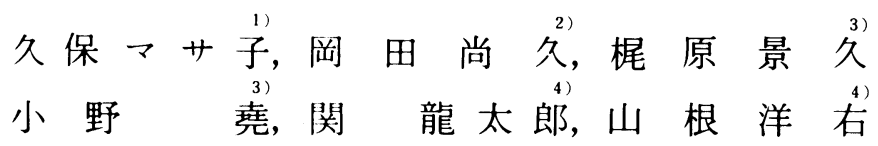

\section{1 はしめに}

日本の資本主義の高度成長政策のしわよせとして生 じる出稼ぎ労動者は年々增加し，その数は 100 万人と も 120 万人ともいわれている。

愛媛県南予においても，農業だけでは生活できず， といって近くに適当な就労先がないため約 1 万人（人 口1,000対30）の出稼ぎ労働者がいるといわれている。 著者らは昭和 41 年より愛媛県東宇和郡宇和町において 共同保健計画にもとづく地区診断を行なってきた。問 題発見一一目標選定一一実践計画一実践一一評価を くりかえしてきた。地区診断の過程において問題とな った出稼ぎ労働者の健康破壊とその社会的背景につい て報告する。第 1 報では明間地区における出稼ぎ労働 者の健康破壊について述べる。

\section{2 查地区概況}

愛媛県東宇和郡宇和町明間地区は, 愛媛県の南予に 位置し, 南予随一の河川の肱川(上流を宇和川とよぶ) が源を発している。明間地区は宇和川ぞいの山間に散 在する 7 つ集落より構成されている。耕地はほとん と山簏にあり, 释営規模は平均耕地面積53 a である。 人口は1,340名 (男657名女683名), 世帯数294戸, 人口 密度 68.4 である。人口構成は図 1 にみられるごとく「と っくり型」を示している。(昭和 40 年国勢調查)

\footnotetext{
愛媛県八幡浜保健所

愛媛県立北宇和病院農村医学センター

愛媛県宇和町

4) 鳥取大学医学缡医動物学教室

受付：昭和 46 年 3 月 12 日
}

図 1 明間地区人口構成および出稼ぎ労働者 （昭和 40 年国勢調査より）

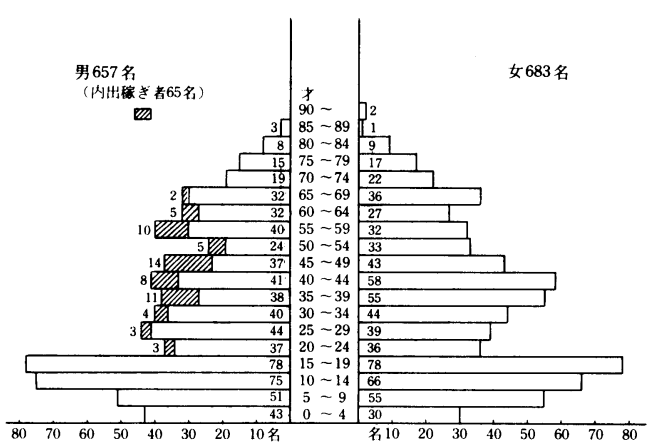

医療機関は明間地区の中央に国保直営診療所がある が, 精密検査を要するもの, 雪科, 産婦人科,外科などは ハスで約20分の宇和町の中心(呏の町) まで出かけね ばならない。夘の町には, 宇和町立病院（内, 外）の ほか10軒の開業医がある。

\section{3 查方法}

昭和43年 8 月に実施した健康診断（全住民を対象） より，明間公民館の資料より出稼ぎ労動者（30〜69才 男子）をえらびだし検討した。同時に受診した30〜69 才の出稼ぎ労動者以外の男子と比較検討した。健康診 断は問診一一検尿一般一一血液検査 (シアンメトへモ グロビンによる血色素, 硫酸銅法による血液比重)—— 血圧測定一一内科診察—必要によっては眼底検查, 心電図一一食生活指導一一生活指導で行なった。同時 に面接フンケートを実施し, 出稼ぎおよび日稼ぎの実 態をあきらかにした。 


\section{4 查結果}

(1) 昭和 43 年 8 月の健康診断の結果は, ...㤃: 労働 者の受診者51名中 32 名 $(62.7 \%)$ になんらかの疾患が みいだされ，疾患数は45件であった。疾患率は，高血 圧症 $15.7 \%$ （8 件), 胃疾患 $15.7 \%$ (8 件), 骨運動器疾 患 $13.7 \%$ （7 件), 負血症 $10.2 \%$ （6 件）などであった。 45件中13件は医師にかかるよう指導された。
潜在疾病をみると $68.9 \%$ をしし，そのらちわけは 「ほったらかし型」の42.2\% (19件)、「きつかず型」 の $26.7 \%$ (12件) である。

出稼ぎ労動者の健康破壊の実態を同じ年代のその他 の住民と比較すると，出稼ぎ労働者の受診率 $76.1 \%$, 有病率 $62.7 \%$, 潜在疾病率 $68.9 \%$ に対して，その他の 住民では，受診率 $55.3 \%$, 有病率 $68.5 \%$, 潜在疾病率 $62.6 \%$ であった。すなわち，その他の住民と比較して

衰 1 出稼ぎ労働者の健康之意識

\begin{tabular}{|c|c|c|c|c|}
\hline & & 出稼ぎ労働者 & その他の住民 & 計 \\
\hline 対 & 数 （人） & 67 & 195 & 262 \\
\hline 受 & 数 （人） & 51 & 108 & 159 \\
\hline 受 & 率 $(\%)$ & 76.1 & 55.3 & 60.7 \\
\hline 病 & 数 （人） & 32 & 74 & 106 \\
\hline 病 & 率 $(\%)$ & 62.7 & 68.5 & 66.7 \\
\hline 疾 & 数 （件） & 45 & 123 & 168 \\
\hline $\begin{array}{l}\text { 潜 在 } \\
\text { 疾 }\end{array}$ & $\begin{array}{l}\text { がまん 型 (件) } \\
\text { きつかず型 (件) }\end{array}$ & $\begin{array}{l}19 \\
12\end{array}$ & $\begin{array}{l}49 \\
27\end{array}$ & $\begin{array}{l}68 \\
39\end{array}$ \\
\hline 潜 在 疾 & 病 率 $(\%)$ & 68.9 & 62.6 & 63.7 \\
\hline $\begin{array}{l}\text { 現在の生活に満 } \\
\text { 足ですか }\end{array}$ & $\begin{array}{llll}\text { 満 } & & \text { 足 } \\
\text { 不 } & & & \text { 満 } \\
\text { わ } & & \text { 小 } & \text { 小 }\end{array}$ & $\begin{array}{l}39.2 \%(20 \text { 人) } \\
35.3 \% \text { (18人) } \\
25.5 \%(13 \text { 人) }\end{array}$ & $\begin{array}{l}56.3 \%(58 \text { 人) } \\
26.2 \%(27 \text { 人) } \\
17.5 \%(18 \text { 人) }\end{array}$ & $\begin{array}{l}50.6 \% \text { (78人) } \\
29.2 \% \text { (45人) } \\
20.1 \% \text { (31人) }\end{array}$ \\
\hline $\begin{array}{l}\text { お子さんにあと } \\
\text { をつがせますか }\end{array}$ & $\begin{array}{l}\text { 継 が } \\
\text { 継 が せ } \\
\text { 子供の自主性にまかす } \\
\text { わ か ら な }\end{array}$ & $\begin{array}{l}29.4 \% \text { (15人) } \\
17.7 \% \text { (9人) } \\
23.5 \% \text { (12人) } \\
29.4 \% \text { (15人) }\end{array}$ & $\begin{array}{l}32.0 \%(33 \text { 人) } \\
27.2 \% \text { (28人) } \\
28.2 \%(29 \text { 人) } \\
12.6 \% \text { (13人) }\end{array}$ & $\begin{array}{l}31.2 \% \text { (48人) } \\
24.0 \% \text { (37人) } \\
26.6 \% \text { (41人) } \\
18.2 \% \text { (28人) }\end{array}$ \\
\hline
\end{tabular}

(30才 69才の男子)

出稼ぎ労働者は受診に対する関心がふかく，有病率は ひくく，潜在疾病率は高い。

(2) 同時に実施した面接アンケート調査においては, 現在の生活に満足の人は $39.2 \%$ ，息子をつがせたいと 考えている人は $29.4 \%$ であった。出稼ぎ労働者以外の 住民では，現在の生活に満足の人は $56.3 \%$ ，息子をつ

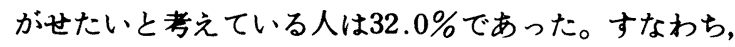
出稼ぎ労働者はその他の住民と比較して, 現在の生活 によりつよく不満を感している傾向が汉られた。後継 者については差はみられなかった。

(3) 同時に実施した出稼ぎ実態調査によれば，出稼 ぎの開始は全体の 8 割にあたる44名が昭和37年以後に 開始しておる。特に昭和38年に開始したものが19名も いる。

仕事内容については, 昭和 42 年の出稼ぎ労働者 42 名 を対象に調査したが，土木関係が過半数の26名（61.9
\%) であり，以下，建設関係 8 名 $(19.0 \%)$, スレート 工場 2 名, 大工 2 名, 左官 1 名, 運転手 1 名, 測量関 係 1 名, かんゔめ工場 1 名であった。すなわち，土木 建設業が大部分をしめ，製造業はそれほど多くない。

昭和 42年の出稼ぎ労働者に 1 4月の給与をたずねた が，回答した 40 名中，3 万円台 $25 \%$ (10名), 5 万円台 $25 \%$ (10名), 4 万円台 $22.5 \%$ (9 名), 6 万円台 $15 \%$ (6 名), 2 万円台 $7.5 \%$ ( 3 名), 7 万円台 1 名, 1 万円台 1 名 である。すなわち，月給 5 万円未満が全体の $57.5 \%$ を しめており，とらてい，労働者としての一家の生活を 保障するほどの金額でない。

出稼ぎの期間は大部分のものは，11月のとりいれを すんでから， 5 月の田づくり前までの 6 ヶ月であるが, なかには，11ヶ月〜12ヶ月の人もみられた。

このよらな現状の出稼ぎを「つづけるかどらか」を 專ねたが，回答した 51 名中，つづけるが56.9\%の29名， 
つつけけなが23.5\%の12名，わからないが19.6\%の10 名であった。すなわち, 明間地区においては生きてゆ くためには「出稼ぎ」以外の仕事がない以上，つづけ ざるを得ない人が大部分であると考えられる。

4 出稼ぎ実態調査にて, 出稼ぎ先での事故, 賃金 の不厸の実態, 出稼先の労働条件などを尋ねたが，な かに次のよらな事例があった。

〔事例〕 国○秀 $\bigcirc 58$ 才男子

昭和 41 年11月 1 日地区診断における出稼ぎ者健康診 断にて, 血圧値 $185 \sim 95 \mathrm{mmHg}$ (検尿はO. B. ) で, 血 生に注意するよらにいわれた。

昭和 42 年 8 月 22 日, 健康診断にて, 血圧值210 114 $\mathrm{mmHg}$ (検尿 O.B., 心電龱正常) で, 要医療を指導 した。しかしながら，本人はたいしたことがないとい って治療はしなかった。

昭和 42 年 11 月, 出稼ぎに行くことを公民館主事, 保 健婦などはとめたが，本人は出稼ぎに出ざるを得ない 々主張し出かけた。

昭和 42 年 3 月9 25 日, 飯場で 8 時間の労働を終え, 夜 6 時からの残業に出かけるために「パンと牛乳」の夕 食を終えて出かけよらとしたところ脳卒中の発作を起 し死亡した。

5.出稼ぎ労働者が $3 \sim 4$ 軒に 1 軒の割合でいる明 間地区であるが，時期を同じくして「メリヤス工場通 いの主婦」が增えつつある。すなわち，女子の日稼ぎ が, 従来からあるところの, 田植 (15名),ひきこ（4
名), 鉱婦（1 名）にくわえて, 土工（8名), メリヤス 工場の編子（17名）がみられている。今回の実態調查 時においても，夫が出稼ぎ，主婦がメリヤス工場の編 子の家庭が 5 軒みられた。今後の明間地区の地区組織 活動および子供の教育, 有児に関する影鳘は大なるも のであろら。

\section{5}

出稼ぎ問題に関して，数多くの研究がある。金崎は 全国的に視野をひろげ，歴史的な研究をふまえて述べ ている。美土路は昭和 36 年の農業基本法の後增加した 出稼ぎに注目し述べている。林は出稼ぎ労働力の地帯 別特性と農業経営の変容について述へ，水野は季節 労働者の生活と失業保険について述べている。農政調 査時報では1965年に「農家の出稼ぎに関する現状と問 題点について, 農林省, 秋田, 新潟の資料で述べ, さ らに留守家族の問題に関しては1968年に述べている。 7)8 しかしながら, 社会医学面からの研究は少なく, 天 明，立身などの研究をみるにすぎない。

調査対象地区の明間地区は，美土路が著書「出稼ぎ」 のなかに数回にわたって引用している地区である⿸尹口゙

出稼ぎ労働者の健康診断のこころみは, 天明らによ って, 勒新団体の主催する「出稼ぎ大会」の会場でこ ころみられている。今回の明間地区の健康診断は, 「健 康をまもる運動」を, 宇和町, 明間公民館, 宇和保健 所，農村医学センターなどの関倸諸機関の協力によっ

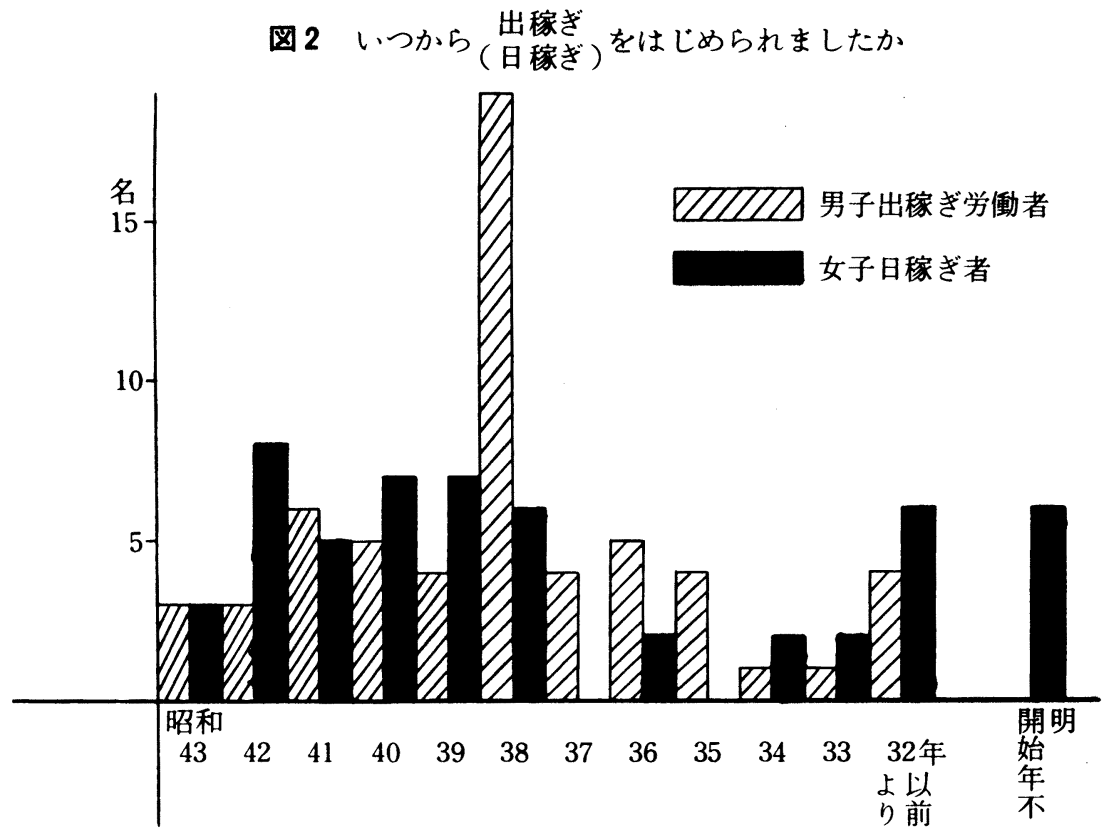


ておしすすめられるなかでとりくまれたものである。 すなわち, 昭和 41 年以来, 共同保健計画にもとついて 地区診断が行なわれている。例えば，健康診断は，昭 和41年11月（対象全住民）, 昭和42年11月（昭和41年の 異常者), 昭和 43 年 8 月 (全住民),に行なわれている。 今回の健康診断の結果, 出稼ぎ労働者51名中32名 (62.7 \%) になんらかの疾患がみいだされ，その5ち13件は 要医療である。しかもそれらの疾患の68.9\%は「がま ん型」さつかず型」とよばれる潜在疾病である。事例 にみられるよらな事故があとをたたない。不健康な労 働者が，疾病の管理すら出来ないまま出稼ぎせざるを 得ない状態をどのよらに考えればいいのであろらか。 しかしながら一方同時に受診した同じ年代の出稼ぎ労 働者以外の人達と比較すると, 出稼ぎ労働者は受診に 対しての関心がふかく, 有病率は低く, 潜在疾病率は 高いといら結果が得られ, 明間地区においては出稼ぎ 労働者の健康破壊だけが問題でなく, 地区全体の健康 破壊が問題である。今後の「健康をまもるたたかい」 は地区ぐるみでおしすすめる必要が考えられる。

出稼ぎ労働者の健康診断の内容については, 健康診 断の目的があらゆる病気の早期発見にくわえて, 出稼 ぎ先で問題となる「脳卒中」事故」結核」性病」など があるので, 問診——胸部 X線一一農夫症調查一一疲 労調査一体重測定一一尿一般検査一一血液一般検査 一一血圧測定一一電図検查一一眼底検査一一 ルマン反応一内科診察—栄養指導一一生活指導は 必須となる。できれば, 胃部レントゲン検査, 体力測 定，血沈などもくわえるべきであろら。

住民自身の主体的な力でもって健康をまもる運動を す寸めるといら視点からして，健康診断と同時に, 「出 稼ぎ先の実態」留守家族および地域の実態」出稼ぎ労 働者の権利意識」などは必らず調査すべきである。

出稼ぎ労働者の現在の生活に対する意識はその他の 住民と比較して, 現在の生活によりつよく不満を感じ ている傾向がみられ，今後の明間地区の健康をまむる 運動をす寸める際考慮すべき点であろら。

同時に実施した明間地区の出稼ぎ実態調査によれば, 出稼ぎ労働者の急増が昭和38年であり,これは農業基 本法の開始に代表される日本農業の貧農きりすて政策 にほぼ一致している。しかも，明間地区においては， 主婦もメリヤス工場通いの労働者化していくのが同年 頃である。すなわち，これらのことは，農業を破壊し ていった日本の資本主義のひとつのあらわれである。 調査結果では, 従来の調査と大差なく，土木および建 設の仕事が多く，1ヶ月の給与は 4 5 万円，期間は 6 ヶ月といら人が多かった。
今後の課題は, 明間地区の健康をまもる活動のなか でどのよらにして「出稼ぎ労働者の健康破壊を防ぐ か」である。今回の調査結果でもあきらかなよ5に， 出稼ぎ労動者のみの健康破壊でない。明間地区の寸べ ての人の健康が破壊されている。

明間地区で生活している人達が，住民の権利にもと ついた主体的な運動をとりくんでいくか，今後の課題 である。そのなかで，出稼ぎ労働者としての権利にめ ざめた人達のはたすやくわりも大きい。

また，地区住民の健康をまもるためには，行政の諸 機関の積極的な働きかけが，要請されているのではな かららか。

\section{6 結}

1) 昭和 41 年来, 共同保健計画のもとに健康管理活 動のとりくまれている愛媛県東宇和郡宇和町明間地区 において，昭和 43 年 8 月，健康診断が行なわれた。

(2) 健康診断の結果, 出稼ぎ労働者の有病率 $62.7 \%$, 潜在疾病 $68.9 \%$ であった。しかしながら、この結果は, 同年代の出稼ぎ労働者以外の住民と比較して有病率は ひくく，潜在疾病は高かった。

(3) 同時に，出稼ぎの実態調査を行ない，明間地区 における事態をあきらかにした。

(4) 明間地区の健康をまもる運動をすすめるさい, 住民の主体性にもとづく活動が必要であり, 出稼ぎ労 働者のはたすやくわりは大きい。

(5) 関係諸機関は地区ぐるみの健康管理活動のなか に「出稼ぎ労働者」を位置つけ，積極的に住民のなか に出かけることが要請されている。

おわりに、ご協力いたたいた宇和保健所, 宇和町, 農村医学 センター，䀢動物学教公のみなさんに感謝致します。

\section{女}

1) 出稼ぎと留守家庭の諸問題；農政調査時報

$159: 19-34 \quad 1968.6$

2）金崎出出稼 古書院 東京 1967.11

3）美土路達雄；出稼き，日本経斉新聞社，東京 1965.4

4) 林喜一郎; 出稼ぎ学㗢力の地帯別特性之農業䅅営の変容, 農村研究 $23 \quad 68-88 \quad 1966.6$

5）水野一宇; 季節学働者の生活と失業保険, 北海道労僖研究 $101 \quad 97-145 \quad 1967.3$

6）農家の出稼きに関する現状と問題点について, 農政調査時報 $119 \quad 9-18 \quad 1965.1$

7) 天明佳臣 ; 都市の断面, 三省堂, 東京, 1969.11

8）天明佳臣・藤勇治；出稼き相談，家の光協会 東京 1970.10

9）立身政一; 出稼き問題にどら対処するか、公臬衛生 $29(4)$ $219-221 \quad 1965.4$ 
The State of Health of the Farmers in a Remote Mountainous Agricultural Village, Who Annually Go to Cities for Seasonal Employment, and its Social Background

Report 1. On the Ruined Health of the Farmers Annually Going to Cities for Seasonal Employment

M. Kubo, N. Okada, K. Kagiwara, T. Ono

R. Seki and Y. Yamane

Department of Medical Zoology, Tottori University School of Medicine, Yonago, Japan

Since 1966 a movement for protecting health has been pushed forward in Akanma District, HigashiUwa-Gun, Ehime Prefecture, under the community program of health protection.

As a result of the medical examination, which was carried out in August, 1968, it became clear that out of the farmers who annually went cities to work 62.7 per cent were diseased and 68.9 per cent were latently diseased. Compared with the other inhabitants of the district, of whom 68.5 per cent were diseased and 62.6 per cent were latently diseased, they were lower in the rate of the diseased and higher in the rate of the latently diseased. At the same time we investigated the living and labor conditions of these farmers.

To reach the real solution of the problem in future it will be necessary that the community program of health protection should be carried out based on the subjecthood of the people in the district. In order to protect the health of the people in Akanma District we shall need the movement fitting with the actual conditions of the district and pushed under the leadership of the people themselves. The solution of the problem on health of the farmers going to cities will also become possible in this movement.

At the same time we would demand the active encouragement by the administrative organs. 